\title{
Spatial and temporal patterns of Ambystoma tigrinum virus (ATV) prevalence in tiger salamanders Ambystoma tigrinum nebulosum
}

\author{
Amy L. Greer ${ }^{1,3, *}$, Jesse L. Brunner ${ }^{1,2}$, James P. Collins ${ }^{1}$ \\ ${ }^{1}$ School of Life Sciences, PO Box 874501, Arizona State University (ASU), Tempe, Arizona 85287-4501, USA \\ ${ }^{2}$ State University of New York, College of Environmental Science and Forestry, 1 Forestry Drive, Syracuse, \\ New York 13210, USA \\ ${ }^{3}$ Present address: Child Health Evaluative Sciences, The Research Institute of the Hospital for Sick Children, \\ 123 Edward Street, Suite 420, Toronto, Ontario M5G 1E2, Canada
}

\begin{abstract}
Amphibian ranaviruses have been documented as causes of mass mortality in amphibian populations throughout the world. The temporal and spatial dynamics of ranavirus infections when epidemics are not apparent remains unclear. To address this question, we collected tissue samples from 2003 to 2006 in 4 geographically separated tiger salamander Ambystoma tigrinum nebulosum host populations on the Kaibab Plateau in northern Arizona. We tested for Ambystoma tigrinum virus (ATV), a lethal ranavirus of tiger salamanders, calculated ATV prevalence for each sampling date, and examined temporal and spatial patterns by quantifying the annual level of ATV synchrony among populations using the intraclass correlation coefficient. Salamander populations were commonly infected with ATV. We observed no morbidity or mortality in these populations even as ATV prevalence values varied from 0 to $57 \%$. Infection prevalence across the landscape was more similar within a given year than between years. There was no statistically significant spatial pattern in prevalence across the landscape. Our findings highlight the need to explore new hypotheses regarding the population level impact of these pathogens on amphibian communities.
\end{abstract}

KEY WORDS: Ambystoma tigrinum nebulosum • Ambystoma tigrinum virus · Amphibian · ATV · Population dynamics $\cdot$ Disease prevalence $\cdot$ Ranavirus

Resale or republication not permitted without written consent of the publisher

\section{INTRODUCTION}

Ranavirus outbreaks in nature are catastrophic for larval amphibians with reports detailing mass morbidity and mortality of hundreds to thousands of larvae. Ranaviral disease outbreaks are apparently common in natural populations and widespread, having been reported in North America, South America, and Europe (Bollinger et al. 1999, Green et al. 2002, Greer et al. 2005, Fox et al. 2006, Cunningham et al. 2007). Indeed, most disease-related mortality events in amphibians in North America have been attributed to ranaviral disease (Bollinger et al. 1999, Greer et al. 2005). There are no data, however, documenting ranavirus infection prevalence in natural amphibian populations in the absence of an epidemic of disease. In the tiger salamander ranavirus (Ambystoma tigrinum virus, ATV) system, for instance, nearly every isolate has come from an epidemic of ranaviral disease. The cycle of persistence has been pieced together from a few observations and laboratory experiments (Brunner et al. 2004), but the temporal and spatial dynamics of ATV prevalence outside of these epidemics is unclear.

We examined the spatial and temporal patterns of ATV infection prevalence in naturally occurring tiger salamander Ambystoma tigrinum nebulosum populations using $4 \mathrm{yr}$ of data from the Kaibab Plateau in northern Arizona to answer 3 questions: (1) Are there infected but asymptomatic larvae in ponds across the 
landscape throughout the growing season? (2) Does ATV prevalence vary spatially and temporally across the landscape? (3) Is ATV prevalence synchronized among ponds across the landscape? We hypothesized that due to the long-term evolution of ATV and tiger salamander populations on the Kaibab Plateau we would find asymptomatic ATV infections, and ATV prevalence would vary both spatially and temporally across the Plateau.

\section{MATERIALS AND METHODS}

Host and virus biology. Tiger salamanders Ambystoma tigrinum nebulosum can be found in ponds and cattle tanks across much of the western United States (Collins 1981). Their life history is seasonal. Breeding occurs in early spring, and larval individuals spend the summer in ponds until metamorphosis in late summer. Newly metamorphosed young of the year move into nearby terrestrial retreats, e.g. mammal burrows, to overwinter. Sexually mature metamorphosed individuals return to ponds to breed in early spring. In northern Arizona where we conducted the present study, sexually immature young of the previous year typically do not return to the pond to breed their first season as a metamorph (Berna 1990). Metamorphs may remain in the ponds for several days, weeks, or months (Collins 1981).

ATV is a large double-stranded DNA ranavirus (Chinchar 2002) that is directly transmitted to susceptible hosts after contact with an infected individual (Brunner et al. 2005, 2007). Epidemics in larval populations typically occur in mid- to late summer and can recur annually (Collins et al. 2004). The reintroduction of the pathogen each year is attributed to sublethally infected adults returning to breed, dubbed an intraspecific reservoir (Brunner et al. 2004). Infected larvae develop systemic infections and typically die 10 to $14 \mathrm{~d}$ after exposure (Jancovich et al. 1997, 2001).

Field sites. We used 4 ponds in North Kaibab National Forest as focal ponds during this 4 yr study (2003 to 2006). The Kaibab Plateau in northern Arizona is approximately 250000 ha of mixed conifer forest with elevations from about 2000 to $3000 \mathrm{~m}$. Many ponds and stock tanks are scattered across this northern Arizona landscape and most support tiger salamander populations. Corral $\left(\mathrm{CR}_{i} 36^{\circ} 37.070^{\prime} \mathrm{N}\right.$, $\left.112^{\circ} 15.034^{\prime} \mathrm{W}\right)$, Mile and a half $\left(\mathrm{MH}_{i} 36^{\circ} 37.016^{\prime} \mathrm{N}\right.$, $\left.112^{\circ} 13.156^{\prime} \mathrm{W}\right)$, Joe's Mudhole $\left(\mathrm{JMH}_{i} 36^{\circ} 34.627^{\prime} \mathrm{N}\right.$, $\left.112^{\circ} 12.649^{\prime} \mathrm{W}\right)$ and Snipe ( $\mathrm{SN}_{i} 36^{\circ} 31.903^{\prime} \mathrm{N}$, $112^{\circ} 12.492^{\prime} \mathrm{W}$ ) are all stock tanks modified by trenching, making them less ephemeral than many Kaibab ponds. CR and MH are $2.8 \mathrm{~km}$ apart; JMH is $4.5 \mathrm{~km}$ from $\mathrm{MH}$ and $5.8 \mathrm{~km}$ from $\mathrm{CR}_{i}$ and $\mathrm{SN}$ is the most dis- tant pond, $9.5 \mathrm{~km}$ from $\mathrm{MH}, 10.3 \mathrm{~km}$ from $\mathrm{CR}$, but just $4.9 \mathrm{~km}$ from JMH (Fig. 1). Heavy winter snowfalls on the plateau mean ponds are accessible only from late May to mid-October. No adult branchiate salamander phenotypes occur here and larvae do not overwinter in ponds (Collins et al. 1993). Salamanders are only present in the ponds from ice-off (late May) until late August (depending on weather conditions). $\mathrm{CR}, \mathrm{MH}$, $\mathrm{JMH}$, and SN all experienced epizootics as far back as the early to mid-1980s (Zerba 1989, Berna 1990, Brunner 2004). There is no evidence of local extinctions of host populations.

Collection of field samples. Salamanders were caught at each pond throughout each season by seining, dip-netting, small mesh minnow traps, and hand. Each animal was tail-clipped (i.e. non-lethally sampled for virus screening and DNA analysis) using a previously published technique (Greer \& Collins 2007) and tagged using visible implant elastomer tags (VIE; Northwest Marine Technology) according to date and year of capture. Each animal was examined for a VIE tag indicating a previous capture. Metamorphosed individuals (both adults and young of the year) were VIE-tagged according to the pond and year of capture. Animals were not tagged with VIE during 2003. A $1 \mathrm{~cm}$ length piece of tissue was removed from the tip of the tail with a sterile, single-use razor blade. Tissue

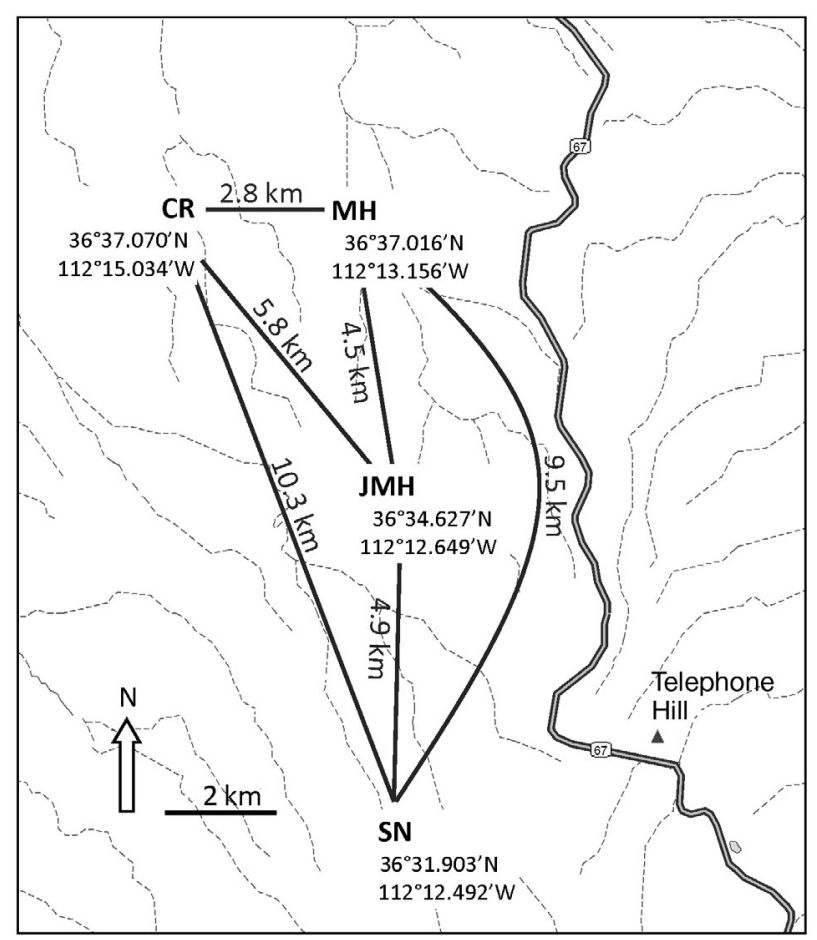

Fig. 1. Locations of ponds used in the present study on the Kaibab Plateau in northern Arizona. CR: Corral; MH: Mile and a half; JMH: Joe's Mudhole; SN: Snipe 
samples were placed in $1.5 \mathrm{ml}$ tubes containing $70 \%$ ethanol, except for those collected in 2003, which were stored in amphibian phosphate buffered saline (APBS) on ice until return to the laboratory and then frozen at $-80^{\circ} \mathrm{C}$. All animals were examined for external clinical signs of ATV infection including edema, papules, lesions, and bloody exudate from the vent (Jancovich et al. 1997). Each animal was handled using a new pair of powdered latex gloves and single-use blades in order to prevent the possible transmission of ATV between animals as a result of handling. After completing work at each pond, all equipment (e.g. nets, waders) was decontaminated using a bleach solution before moving to a new location.

Screening samples for ATV. We screened tissues for ATV using a PCR protocol (Mao et al. 1997, Greer \& Collins 2007). Frozen tissues were lysed in $500 \mu \mathrm{l}$ of $1 \times$ cell lysis buffer and $2 \mu \mathrm{l}$ of proteinase $\mathrm{K}\left(14.4 \mathrm{mg} \mathrm{ml}^{-1}\right.$, $>60.0 \mathrm{U} 100 \mathrm{\mu l}^{-1}$ ). Tubes were vortexed and incubated at $37^{\circ} \mathrm{C}$ overnight. Tubes were vortexed once more before being frozen at $-20^{\circ} \mathrm{C}$ prior to DNA extraction. Extractions of total cellular DNA were completed using a standard extraction protocol (Sambrook \& Russell 2001). Each sample had $100 \mu$ l of protein precipitation solution added. Tubes were vortexed and then centrifuged at $21000 \times g$ for $10 \mathrm{~min}$. The resulting supernatant was aspirated into a new $1.5 \mathrm{ml}$ tube. Three hundred $\mu \mathrm{l}$ of $100 \%$ isopropanol were added to each sample and tubes were mixed by inverting approximately 50 times. Samples were then centrifuged at $15800 \times g$ for $5 \mathrm{~min}$. The resulting supernatant was poured off leaving the DNA pellet within the tube. Pellets were washed with $300 \mu \mathrm{l}$ of $70 \%$ ethanol and then centrifuged at $15800 \times g$ for $3 \mathrm{~min}$. Supernatant was poured off each sample and samples were air-dried overnight (inverted). Dried pellets were diluted in $200 \mu \mathrm{l}$ of molecular quality water and stored in a $-20^{\circ} \mathrm{C}$ freezer until amplification. Ten $\mu \mathrm{l}$ PCR reactions were carried out using PCR primers MCP4 and 5 (Mao et al. 1997). Each reaction included $1 \mu$ of $10 \times$ PCR buffer

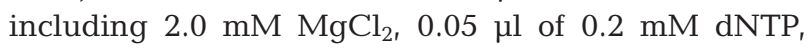
$0.3 \mu \mathrm{l}$ of $0.2 \mu \mathrm{M}$ forward and reverse primer, $0.2 \mu \mathrm{l}$ Taq, $1 \mu \mathrm{l}$ template, and $7.15 \mu \mathrm{l}$ molecular quality water. Thermocycling conditions were similar for all samples $\left(94^{\circ} \mathrm{C}\right.$ for $5 \mathrm{~min}, 94^{\circ} \mathrm{C}$ for $30 \mathrm{~s}, 55^{\circ} \mathrm{C}$ for $30 \mathrm{~s}$, and $72^{\circ} \mathrm{C}$ for $30 \mathrm{~s}$, cycled 35 times followed by an extension of $72^{\circ} \mathrm{C}$ for $\left.2 \mathrm{~min}\right)$. Amplified product was visualized on $1 \%$ agarose gels. All samples testing negative for ATV were screened a second time to verify the negative result. This testing methodology produces false positives only as a result of sample contamination; therefore, both positive and negative controls were tested alongside all unknown samples. Positive controls were DNA samples from experimentally infected tiger salamanders known to be infected with ATV (animals died as a result of their infection and were both cell-culture and PCR-positive). Negative controls included extraction controls that were carried alongside all unknown samples throughout the protocol in order to assess carryover contamination from sample preparation. Negative virus controls were tiger salamanders that were known to be uninfected by ATV (non-symptomatic and both cell-culture and PCR-negative). Cocktail controls were samples that contained only PCR cocktail and no DNA to assess possible contamination of the cocktail reagents with ranavirus DNA. All negative controls were always completed last and without changing gloves as a means of identifying contamination. Each step (extraction, amplification, and visualization) was performed in an area of the lab dedicated to that purpose using dedicated equipment to prevent crosscontamination. All equipment (e.g. tip boxes, pipettes) was sterilized by UV light between uses.

Estimating ATV prevalence. ATV prevalence was estimated for each pond and sampling date by dividing the number of positive samples by total number of individuals collected. This yielded the apparent prevalence within the population. However, the sensitivity of our test is low for animals that are newly infected $(<5 \mathrm{~d})$, so we converted the apparent prevalence value to an estimated true prevalence value based on the known sensitivity and specificity of the diagnostic test (Greer \& Collins 2007). Confidence intervals were estimated based on the sample size collected following Dohoo et al. (2003). For example, if only 30 tissue samples were obtained for a specific sampling date and all samples were negative, this indicated that we could be $95 \%$ confident that the true prevalence of disease was at or less than $10 \%$; the true prevalence for this date could take any value from 0 (the apparent prevalence) to $10 \%$. Each sampling season was defined as the period from June 1 to September 1 for a total of $93 \mathrm{~d}$ per year. This 'season day' was used to plot all prevalence figures with time on the abscissa instead of date to display all 4 yr of data on one figure.

To describe the temporal trends in prevalence, we fit 4 non-linear models (a single Gaussian, cubic, quadratic, or 4 th degree polynomial) to each of the 2004 field prevalence datasets (1 per pond) using a maximum likelihood approach implemented in Matlab (Mathworks). We then used the Akaike Information Criterion corrected for sample size $\left(\mathrm{AIC}_{\mathrm{c}}\right)$ and $\mathrm{AIC}$ weights to compare models. Curves were not fit to the 2003 and 2005 datasets because of too few data.

Evaluating disease synchrony. We calculated the intraclass correlation coefficient (ICC, $\mathrm{r}_{\mathrm{i}}$ ) as a measure of synchrony between populations (Zar 1984, Dohoo et al. 2003, Fontaine \& Gonzalez 2005). The ICC is a pairwise measure that quantifies the correlation between observations and estimates homogeneity. Values of $r_{i}$ 
close to 1 indicate complete synchrony, while values approaching -1 indicate a complete lack of synchrony. We calculated ICC values from the disease prevalence data at each time interval. The ICC is a more precise measure than Pearson's product-moment correlation coefficient when the sample sizes are small or more than 2 groups are being compared. We also used coincidence of peaks to compare sites qualitatively using the number, dates, and severity of peaks (Buonaccorsi et al. 2001).

\section{RESULTS}

\section{ATV in larval salamander populations on the Kaibab Plateau}

Sample sizes varied between years and for different life history stages. The most larvae were collected in 2004 ( $\mathrm{N}=1462)$; smaller numbers were collected in $2003(\mathrm{~N}=363)$ and $2005(\mathrm{~N}=335)$. Only 149 larvae were collected in 2006 due to an extremely active fire season on the Kaibab Plateau. Each year larvae metamorphosed in August with few remaining by September. Most adult metamorphs were collected in 2003 $(\mathrm{N}=53)$. Thirty-seven juvenile metamorphs were captured in 2004, and 37 were captured in 2005. Only 2 adult metamorphs were collected in 2006. No animals captured from the 4 ponds during the $4 \mathrm{yr}$ period had external clinical signs of ATV infection. All tissue samples collected in 2003 and 2006 were negative for the disease. At least some larvae sampled in 2004 and 2005 tested positive for ATV, despite a lack of clinical signs of disease. Disease prevalence peaked at $57 \%$ in some ponds (Fig. 2). Peak ranavirus prevalence was highest in 2004, lower in 2005, and undetectable in 2003 and 2006 (Fig. 2). Data collected in 2004 appeared to have 2 peaks (1 early in the season and 1 later in the season); however, the curve with a single mode was best supported by the data, according to $\mathrm{AIC}_{\mathrm{c}}$ (Table 1).

\section{Disease synchrony}

Since no ponds had detectable disease in 2003 and 2006 they were, by definition, synchronous. In the 2 remaining years, ponds were more similar within a year than between years (Fig. 2).

In 2004, salamanders in all 4 ponds were ATV-positive on multiple sampling dates. JMH and SN were highly synchronized $\left(\mathrm{r}_{\mathrm{i}}=0.924\right)$ : both ponds had peaks of similar size on the same sampling date. The 2 ponds in closest proximity (CR and $\mathrm{MH}$ ) were less synchronized $\left(r_{i}=0.346\right)$ than more distant ponds (Fig. 1). CR

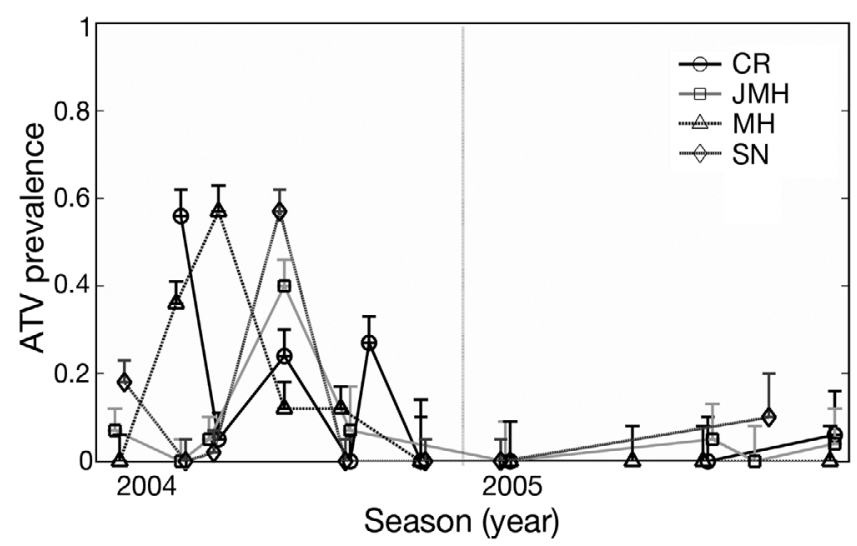

Fig. 2. Mean prevalence of Ambystoma tigrinum virus (ATV) in susceptible larvae in 4 ponds ( $\mathrm{CR}, \mathrm{MH}, \mathrm{JMH}$ and $\mathrm{SN}$ ) between 1 June and 1 September 2004 and 2005. Bars are 95\% confidence levels based on the sample size for each date. Data for 2003 and 2006 are not plotted as no ATV was detected in these samples. Dashed line indicates the end of one larval season and beginning of the next. See Fig. 1 for pond name abbreviations

Table 1. Maximum likelihood fit of non-linear models to disease prevalence data (2004) from 4 different populations on the Kaibab Plateau, Arizona. Model functions examined included a single Gaussian and 3 types of polynomials. AIC: Akaike's information criterion; $\mathrm{AIC}_{\mathrm{C}}$ : $\mathrm{AIC}$ corrected for sample size and number of parameters; $\Delta i$ : difference between $\mathrm{AIC}_{\mathrm{c}}$ of model $i$ and lowest $\mathrm{AIC}_{\mathrm{c}}$ value; $\mathrm{w}_{i}$ : Akaike weights for each model $i$. See Fig. 1 for pond name abbreviations

\begin{tabular}{|llrrrr|}
\hline \multirow{2}{*}{ Pond } & \multicolumn{1}{c}{ Model function } & $\mathrm{AIC}$ & $\mathrm{AIC}_{\mathrm{c}}$ & $\Delta i$ & $\mathrm{w}_{i}$ \\
\hline \multirow{2}{*}{$\mathrm{JMH}$} & Gaussian & -6.4 & -90.4 & 0.0 & 1.00 \\
& Quadratic polynomial & -12.5 & -0.5 & 89.9 & 0.00 \\
& Cubic polynomial & -5.0 & 7.0 & 97.4 & 0.00 \\
& 4th degree polynomial & -4.0 & 36.0 & 126.4 & 0.00 \\
$\mathrm{MH}$ & Gaussian & -12.8 & -4.8 & 0.0 & 0.97 \\
& Quadratic polynomial & -5.6 & 2.4 & 7.2 & 0.03 \\
& Cubic polynomial & -3.6 & 16.4 & 21.2 & 0.00 \\
& 4th degree polynomial & -4.3 & 55.7 & 60.4 & 0.00 \\
& Gaussian & -10.3 & 33.1 & 0.0 & 0.95 \\
& Quadratic polynomial & -4.3 & 39.1 & 6.0 & 0.05 \\
& Cubic polynomial & -2.6 & 40.9 & 19.8 & 0.00 \\
& 4th degree polynomial & -0.6 & 42.9 & 61.7 & 0.00 \\
& Gaussian & -6.1 & 1.9 & 0.0 & 0.62 \\
& Quadratic polynomial & -5.1 & 2.9 & 1.0 & 0.38 \\
& Cubic polynomial & -3.4 & 16.6 & 14.7 & 0.00 \\
& 4th degree polynomial & -2.8 & 57.2 & 55.3 & 0.00 \\
& & & & & \\
\hline
\end{tabular}

and $\mathrm{MH}$ had peaks of similar size, but shifted in the timing of the disease maximum with CR peaking earlier than $\mathrm{MH}$ (Table 2). Ponds most distant from one another $(10.3 \mathrm{~km})$ had similarly sized peaks, but peak timing was discordant (Table 2). No pond pairs were perfectly asynchronized (i.e. $\mathrm{r}_{\mathrm{i}}=-1$ ) in 2004 . 
Table 2. Measures of synchrony for population pairs on the Kaibab Plateau in 2004 and 2005. Estimates of synchrony were not calculated for 2003 and 2006 because the 4 populations had no detectable disease. The dates of maximum prevalence for each population correspond to season days. In 2004, 1 June was Day 103 and the season ran until Day 195 (1 September 2004). In 2005, 1 June was Day 205 and the season ran until Day 297 (1 September 2005). See Fig. 1 for pond name abbreviations

\begin{tabular}{|lccccc|}
\hline $\begin{array}{l}\text { Pair and } \\
\text { year }\end{array}$ & $\begin{array}{c}\text { Distance between } \\
\text { pairs }(\mathrm{km})\end{array}$ & $\begin{array}{c}\text { Intraclass correlation } \\
\text { coefficient }\left(\mathrm{r}_{\mathrm{i}}\right)\end{array}$ & $\begin{array}{c}\text { No. peaks in } \\
\text { prevalence }\end{array}$ & $\begin{array}{c}\text { Maximum prevalence } \\
\text { for each population }\end{array}$ & $\begin{array}{c}\text { Date of maximum } \\
\text { prevalence for } \\
\text { each population }\end{array}$ \\
\hline CR:MH (2004) & 2.80 & 0.35 & $1: 1$ & $0.56: 0.57$ & $138: 146$ \\
CR:MH (2005) & 2.80 & 0.00 & $1: 0$ & $0.06: 0.00$ & $277: 208$ \\
MH:JMH (2004) & 4.49 & -0.21 & $1: 1$ & $0.57: 0.40$ & $146: 160$ \\
MH:JMH (2005) & 4.49 & -0.32 & $0: 1$ & $0.00: 0.05$ & $208: 250$ \\
JMH:SN (2004) & 4.94 & 0.92 & $1: 1$ & $0.40: 0.57$ & $160: 160$ \\
JMH:SN (2005) & 4.94 & 0.42 & $1: 1$ & $0.05: 0.10$ & $250: 277$ \\
CR:JMH (2004) & 5.76 & 0.14 & $1: 1$ & $0.56: 0.40$ & $138: 160$ \\
CR:JMH (2005) & 5.76 & 0.44 & $1: 1$ & $0.06: 0.05$ & $277: 250$ \\
MH:SN (2004) & 9.53 & -0.20 & $0: 1$ & $0.57: 0.57$ & $146: 160$ \\
MH:SN (2005) & 9.53 & 0.00 & $1: 1$ & $0.00: 0.10$ & $208: 277$ \\
CR:SN (2004) & 10.30 & 0.25 & $1: 1$ & $0.56: 0.57$ & $138: 160$ \\
CR:SN (2005) & 10.30 & 0.88 & $0.06: 0.10$ & $277: 277$ \\
\hline
\end{tabular}

In 2005, ponds most distant from one another (CR and $\mathrm{SN})$ were most synchronized $\left(\mathrm{r}_{\mathrm{i}}=0.882\right.$; Fig. 1$)$. CR and SN experienced similarly sized peaks with the same timing (Table 2). $\mathrm{MH}$ and $\mathrm{JMH}$ were less synchronous $\left(r_{i}=-0.323 ;\right.$ Fig. 1$)$ despite being closer to one another.

\section{Metamorphosed salamanders}

None of the 129 metamorphosed salamanders tested positive for ATV. However, prevalence in returning metamorphs may have been as high as 38\% at a given time in a given pond after adjusting for sample size and the sensitivity and specificity of the diagnostic test (risk of false negatives). Fifteen of 76 marked, metamorphosed salamanders were recaptured, all at their pond of origin rather than at neighbouring or more distant ponds (including ponds not included in the present study).

\section{DISCUSSION}

Using tissue samples collected from ponds across the Kaibab Plateau with histories of ATV outbreaks we found that salamanders in northern Arizona may be commonly infected with ATV in the absence of die-offs or even overt symptoms. During our 4 yr study no salamanders presented clinical signs of ATV infection and no disease outbreaks were observed within these ponds, despite regular sampling and a high prevalence of infection in some years. We emphasize that this does not mean that larvae were not becoming sick and dying of ATV infections, just that this morbidity and mortality was not common enough to be detected. This contrasts strongly with experimental infections of larvae with ATV, which are usually lethal within 2 to $3 \mathrm{wk}$ (Jancovich et al. 1997, Greer et al. 2008), and with previous field reports of ATV-related mortality literally decimating larval cohorts (Bollinger et al. 1999). One possible explanation for these contrasting findings is that tiger salamander populations have evolved, if not resistance to ATV infection, which would result in relatively few ATV-infected animals, then tolerance. We hypothesize that after years of strong selection (i.e. large outbreaks killing most or all susceptible hosts), surviving salamanders are more tolerant of ATV infection such that their offspring do not exhibit clinical manifestations of the disease or experience mortality as a result of the infection. It is also possible that the virus has evolved reduced virulence. Our data cannot resolve these possibilities, but they do highlight the need for more research on host-virus evolution.

We found that ATV prevalence varied greatly across the plateau in space and time. Prevalence was more similar among populations within a year than between years. ATV prevalence was $>50 \%$ in 2004 , but no infected animals were found in 2003 or 2006 . Due to forest fires on the Plateau in 2006, sampling was not possible for much of the summer season, so this observation may be related to low sample sizes. Prevalence data collected in 2004 and 2005 demonstrated that while prevalence fluctuated throughout the year within some ponds, the best supported curve was one with a single peak. Some variation among sampling periods is expected simply because of random variation in samples. Work is underway to examine disease transmission dynamics within this system using a mathematical model to test for mechanisms that could cause a switch from local to global disease transmission dynamics. 
Lastly, synchrony in dynamics between ponds suggests that ATV prevalence was synchronous or nearly synchronous among the 4 ponds within a year and less so between years, but synchrony was difficult to predict. In some years, such as 2004, the ponds that exhibited the most similar dynamics were in fact the ponds that were the most spatially distant from one another, whereas ponds that were in close proximity exhibited very different dynamics. This finding suggests that synchrony in ATV dynamics is not a result of movement of salamanders between ponds or even the prevailing influence of local conditions. Focused, hypothesis-driven experiments are needed to examine the mechanisms that drive synchrony in these populations. They would contribute greatly to our understanding of infectious disease dynamics in wild populations.

Acknowledgements. This work was supported in part by NSF Integrated Research Challenges in Environmental Biology grant no. DEB 0213851 to J.P.C and 22 collaborators. M. Boley, L. Greer, J. Greer, K. Jaeger, M. Kalisz, C. King, V. Miera, H. Nelson, A. Picco, K. Richards-Hrdlicka, B. Ridenhour, D. Schock, J. Wendling, and the Fredonia Arizona Youth Conservation Corp helped to collect tissue samples. This work was authorized under ASU IACCUC protocol no. 06-858R. Arizona Game and Fish and the North Kaibab Ranger District authorized field sampling.

\section{LITERATURE CITED}

Berna HJ (1990) Ecology and life history of the tiger salamander Ambystoma tigrinum nebulosum Hallowell, on the Kaibab Plateau. PhD thesis, Arizona State University, Tempe, AZ

Bollinger TK, Mao JH, Schock D, Brigham RM, Chinchar VG (1999) Pathology, isolation, and preliminary molecular characterization of a novel iridovirus from tiger salamanders in Saskatchewan. J Wildl Dis 35:413-429

Brunner J (2004) Ecology of an amphibian pathogen: transmission, persistence and virulence. PhD thesis, Arizona State University, Tempe, AZ

Brunner JL, Schock DM, Davidson EW, Collins JP (2004) Intraspecific reservoirs: complex life history and the persistence of a lethal ranavirus. Ecology 85:560-566

Brunner JL, Richards K, Collins JP (2005) Dose and host characteristics influence virulence of ranavirus infections. Oecologia 144:399-406

Brunner JL, Schock DM, Collins JP (2007) Transmission dynamics of the amphibian ranavirus Ambystoma tigrinum virus. Dis Aquat Org 77:87-95

Buonaccorsi JP, Elkinton JS, Evans SR, Liebhold AM (2001) Measuring and testing for spatial synchrony. Ecology 82:1668-1679

Editorial responsibility: Alex Hyatt, Geelong, Victoria, Australia
Chinchar VG (2002) Ranaviruses (family Iridoviridae): emerging cold-blooded killers. Arch Virol 147:447-470

Collins JP (1981) Distribution, habitats and life-history variation in the tiger salamander, Ambystoma tigrinum, in eastcentral and southeast Arizona. Copeia 666-675

Collins JP, Zerba KE, Sredl MJ (1993) Shaping intraspecific variation: development, ecology and the evolution of morphology and life-history variation in tiger salamanders. Genetica 89:167-183

Collins JP, Brunner JL, Jancovich JK, Schock DM (2004) A model host-pathogen system for studying infectious disease dynamics in amphibians: tiger salamanders (Ambystoma tigrinum) and Ambystoma tigrinum virus. Herpetol J 14:195-200

Cunningham AA, Hyatt AD, Russell P, Bennett PM (2007) Experimental transmission of a ranavirus disease of common toads (Bufo bufo) to common frogs (Rana temporaria). Epidemiol Infect 135:1213-1216

Dohoo I, Martin W, Stryhn H (2003) Veterinary epidemiologic research. University of Prince Edward Island Press, Charlottetown

Fontaine C, Gonzalez A (2005) Population synchrony induced by resource fluctuations and dispersal in an aquatic microcosm. Ecology 86:1463-1471

$>$ Fox SF, Greer AL, Torres-Cervantes R, Collins JP (2006) First case of ranavirus-associated morbidity and mortality in natural populations of the South American frog Atelognathus patagonicus. Dis Aquat Org 72:87-92

> Green DE, Converse KA, Schrader AK (2002) Epizootiology of sixty-four amphibian morbidity and mortality events in the USA, 1996-2001. Ann NY Acad Sci 969:323-339

> Greer AL, Collins JP (2007) Sensitivity of a diagnostic test for amphibian Ranavirus varies with sampling protocol. J Wildl Dis 43:525-532

Greer AL, Berrill M, Wilson PJ (2005) Five amphibian mortality events associated with ranavirus infection in south central Ontario, Canada. Dis Aquat Org 67:9-14

Greer AL, Briggs CJ, Collins JP (2008) Testing a key assumption of host-pathogen theory: density and disease transmission. Oikos 117:1667-1673

> Jancovich JK, Davidson EW, Morado JF, Jacobs BL, Collins JP (1997) Isolation of a lethal virus from the endangered tiger salamander Ambystoma tigrinum stebbinsi. Dis Aquat Org 31:161-167

Jancovich JK, Davidson EW, Seiler A, Jacobs BL, Collins JP (2001) Transmission of the Ambystoma tigrinum virus to alternative hosts. Dis Aquat Org 46:159-163

> Mao J, Hedrick RP, Chinchar VG (1997) Molecular characterization, sequence analysis, and taxonomic position of newly isolated fish iridoviruses. Virology 229:212-220

Sambrook J, Russell DW (2001) Molecular cloning: a laboratory manual. Cold Spring Harbor Laboratory Press, Cold Spring Harbor, NY

Zar J (1984) Biostatistical analysis. Prentice Hall, Englewood Cliffs, NJ

Zerba KE (1989) Individual variation in the diet of larval tiger salamanders (Ambystoma tigrinum nebulosum) in Arizona. PhD thesis, Arizona State University, Tempe, AZ

Submitted: October 8, 2008; Accepted: March 17, 2009

Proofs received from author(s): May 6, 2009 